\title{
Studies on the Effect of Cytokinin on Growth of African Marigold (Tagetes erecta L.) cv. Pusa Narangi Gainda
}

\author{
Manas Mandal ${ }^{1 *}$, Soumen Maitra ${ }^{1}$, Anamay Sarkar', Bappa Paramanik², \\ Indrajit Sarkar ${ }^{1}$ and Debasis Mahata ${ }^{3}$ \\ ${ }^{1}$ Department of Floriculture and Landscape Architecture, Uttar BangaKrishiViswavidyalaya, \\ Pundibari, Cooch Behar, West Bengal, India \\ ${ }_{2}^{2}$ Soil Science, DakshinDinajpur, KVK, Majhian, Patiram, DakshinDinajpur, \\ West Bengal, India \\ ${ }^{3}$ Agronomy, Uttar DinajpurKrishiVigyan Kendra, Chopra, Islampur, Uttar Dinajpur, West \\ Bengal, India
}

*Corresponding author

\begin{tabular}{|l|}
\hline K e y w o r d s \\
Marigold, \\
cytokinin, Benzyl \\
adenine, full \\
blooming
\end{tabular}

A B S T R A C T

The experiment was carried out in two consecutive years 2016 and 2017 at Uttar BangaKrishiViswavidyalaya, CoochBehar, West Bengal to Studies on the effect of cytokinin on growth of African Marigold (Tagetes erectaL.) cv. PusaNarangiGainda. I was taken twelve different dose such as 25ppm, 50ppm,75ppm, 100ppm, 125ppm, 150ppm, 175ppm, 200ppm, 225ppm, 250ppm, 275ppm, 300ppm and one control.The experiment was conducted following RBD with 12 different levels of cytokinin ranging from $25 \mathrm{ppm}, 50 \mathrm{ppm}, 75 \mathrm{ppm}, 100 \mathrm{ppm}, 125 \mathrm{ppm}$. $150 \mathrm{ppm}$, $175 \mathrm{ppm}, 200 \mathrm{ppm}, 225 \mathrm{ppm}, 250 \mathrm{ppm}, 275 \mathrm{ppm}$ and $300 \mathrm{ppm}$ and compared to control (distilled water spray). The 13 treatments were replicated thrice. Results revealed that application of $25 \mathrm{ppm}$ BA increased the plant height at 21 days after transplanting $(23.19 \mathrm{~cm})$, plant height at 42 days after transplanting $(48.13 \mathrm{~cm})$, leaflet length at 21 days after transplanting $(4.32 \mathrm{~cm})$, Leaflet length at 42 days after transplanting $(6.80 \mathrm{~cm})$, Increase in the girth of stem at 42 days after transplanting was noticed with $275 \mathrm{ppm}$ BA application $(9.36 \mathrm{~mm})$. Initially, side-shoot production was increased with $200 \mathrm{ppm}$ BA application $(4.80 \mathrm{~cm})$ but at 42 days after transplanting higher number of side-shoots was obtained with $150 \mathrm{ppm}$ BA application $(10.80 \mathrm{~cm})$. Shoot length was found maximum with 175 BA application both at 21 days $(2.88 \mathrm{~cm})$ and 42 days after transplanting $(14.0 \mathrm{~cm})$. Leaf production was found maximum with $250 \mathrm{ppm}$ BA application in both at 21 days (3.80) and 42 days (13.07) after transplanting. The same treatment also showed higher leaf length at 42 days after transplanting $(21.86 \mathrm{~cm})$.Though at 21 days leaflet production was higher with $225 \mathrm{ppm}$ BA application (16.07) but at 42 days after transplanting 300 ppm BA application showed higher leaflet production (24.07). Initially $200 \mathrm{ppm}$ BA application improved leaflet length $(4.93 \mathrm{~cm})$ but finally maximum leaflet length was found with $25 \mathrm{ppm}$ BA application. Leaf expansion was observed higher with foliar application of $200 \mathrm{ppm} \mathrm{BA}$ in both at 21 days $(0.96 \mathrm{~cm})$ and 42 days after transplanting $(1.33 \mathrm{~cm})$. Plants treated with same concentration reached the flower bud initiation stage earliest (46.60 days after transplanting). Whereas, $200 \mathrm{ppm}$ solution showed least time period (6.66 days) for flower bud development and from the developing bud to full bloom stage, $25 \mathrm{ppm}$ BA concentration showed the earliness (6.60 days). 


\section{Introduction}

Marigold is one of the most important commercial loose flowers of India (Kumar et al., 2015). Marigolds belong to the genus "Tagetes", which was derived from the Greek word "Tages", the name of Estrucsch God, a demigod, known for the beauty. Marigolds were first discovered by the Portuguese in Central America in the 16th century (Gawleet al., 2012). Genus Tagetes belongs to subfamily Asteroideae (or Tubuliflorae) of family Asteraceae (Panero and Funk, 2002) and is a native to Mexico. Genus Tagetes is a flowering plant represents 56 species, of $\mathrm{w}$ hich 27 are annual and 29 are perennial distributed throughout the world (Soule, 1993a, and Soule 1993b) and it is suitable under tropical and sub-tropical region.

Marigold has several important species, among which five species are cultivated for commercial purpose to some extent (Dixit et al., 2013) namely Tagetes erecta (African Marigold), Tagetes patula (French Marigold), Tagetes tenuifolia (Signet Marigold), Tagetes lucida (Sweet Scented Marigold) and Tagetes minuta(Southern Cone Marigold/ Mexican Marigold).

Nowadays, African Marigold flowers have huge demand in agricultural entrepreneurship due to its multifarious uses (Sudhagar, 2013) so, growth regulator is one and only way to increase of the yield and fulfillof the demand. Growth regulator has several types such as; Auxin, Gibberellin, Cytokinin, Ethylene etc. But among of them except Cytokinin, all other hormone already appliedor already has so many research paper. But the information regarding the effect of exogenous application of cytokinin in the cultivation of African marigold is very scanty. Keeping all these in view the present experiment is proposed to study the effect of exogenous application of cytokinin on growth and quality of African marigold with the following objectives.

\section{Materials and Methods}

The present experiment entitled "Application of Different dose of BA on growth of African marigold" was conducted under the Department of Floriculture, Medicinal and Aromatic Plants, Faculty of Horticulture, Uttar BangaKrishiViswavidyalaya, Pundibari, Cooch Behar, West Bengal, during the year 2016-17. Geographically the farm is situated at an elevation of 43 meter above the mean sea level at $26^{\circ} 19^{\prime} 86^{\prime \prime} \mathrm{N}$ latitude and $89^{\circ} 23^{\prime} 53^{\prime \prime}$ E longitude. According to this research point of view twelve different types dose was taken such as; $\mathrm{T}_{1=} \mathrm{BA} @ 50 \mathrm{ppm}$, $\mathrm{T}_{2=} \mathrm{BA} @ 50 \mathrm{PPM}, \quad \mathrm{T}_{3=} \mathrm{BA} @ 75 \mathrm{ppm}, \quad \mathrm{T}_{4=}$ BA@ $100 \mathrm{ppm}, \quad \mathrm{T}_{5=}$ BA@125ppm, $\quad \mathrm{T}_{6=}$ BA@ $150 \mathrm{ppm}, \quad \mathrm{T}_{7=} \mathrm{BA} @ 175 \mathrm{ppm}, \quad \mathrm{T}_{8=}$ BA@200ppm, $\quad \mathrm{T}_{9=}$ BA@225ppm, $\quad \mathrm{T}_{10=}$ BA@250ppm, $\quad \mathrm{T}_{11}=\mathrm{BA} @ 275 \mathrm{ppm}, \quad \mathrm{T}_{12=}$ BA@300ppm, $\mathrm{T}_{13}=$ Control.

\section{Results and Discussion}

\section{Plant height at 21 days after transplanting (cm)}

The effect of $\mathrm{N}^{6}$ benzyladenine (BA) on plant height of African Marigold cv. PusaNagraniGainda at 21 days after transplanting was found statistically significant. Plants treated with $25 \mathrm{ppm}$ BA showed an increase in the plant height (23.19 $\mathrm{cm})$ which was Statistically at par with the effect of $225 \mathrm{ppm}$ and $100 \mathrm{ppm}$ BA applications $(22.17 \mathrm{~cm}$ and $22.13 \mathrm{~cm}$ respectively), and the later was also on par with the effect of $275 \mathrm{ppm}$ BA application $(21.81 \mathrm{~cm}), 250 \mathrm{ppm}$ BA application $(21.77$ $\mathrm{cm})$ and $150 \mathrm{ppm} \mathrm{BA}$ application $(21.68 \mathrm{~cm})$. Control plants showed the moderate effect of $20.47 \mathrm{~cm}$ which was equally effective with 50 ppm $(20.30 \mathrm{~cm})$ and $75 \mathrm{ppm}(20.33 \mathrm{~cm}) \mathrm{BA}$ applications (Table-4.1). The least plant height was recorded with $300 \mathrm{ppm}$ BA treated plants $(19.55 \mathrm{~cm})$ which was found statistically at par with the effects of $200 \mathrm{ppm}$ 
$(19.79 \mathrm{~cm})$ and $125 \mathrm{ppm}(20.11 \mathrm{~cm}) \mathrm{BA}$ applications (Figure - 4.1).

\section{Plant height at 42 days after transplanting (cm)}

$25 \mathrm{ppm}$ BA treated plants again showed improved plant height $(48.13 \mathrm{~cm})$ of African Marigold cv. PusaNarangiGainda at 42 days after transplanting followed by $100 \mathrm{ppm}$ and $225 \mathrm{ppm}$ (both $47.01 \mathrm{~cm}$ ) BA applications which was statistically at par with $175 \mathrm{ppm}$ $(46.39 \mathrm{~cm})$ BA application. Result at that stage of crop growth was found statistically significant (Table -4.1). Next improved plant height was obtained from $150 \mathrm{ppm}$ (46.17 $\mathrm{cm}), 250 \mathrm{ppm}(46.18 \mathrm{~cm})$ and $275 \mathrm{ppm}(45.77$ $\mathrm{cm})$ BA treated plants (Figure - 4.1).Plants treated with $75 \mathrm{ppm}$ BA showed the minimum plant height $(41.71 \mathrm{~cm})$ of African marigold which was found statistically at par with 300 ppm $(41.95 \mathrm{~cm})$ and $200 \mathrm{ppm}(42.25 \mathrm{~cm}) \mathrm{BA}$ applications as well as control plants (41.89 $\mathrm{cm})$.

\section{Girth of stem at 21 days after transplanting} (mm)

The effect of Benzyladenineon the girth of the stem of African Marigold cv. PusaNarangiGainda at 21 days after transplanting was found statistically significant (Table-4.1). Plants treated with $150 \mathrm{ppm}$ BA solution showed the maximum stem girth $(5.87 \mathrm{~mm})$ followed by $275 \mathrm{ppm}$ BA application $(5.25 \mathrm{~mm})$ which was statistically at par with the effects of $225 \mathrm{ppm}$ $(5.23 \mathrm{~mm}), 175 \mathrm{ppm}(5.22 \mathrm{~mm}), 100 \mathrm{ppm}$ $(5.12 \mathrm{~mm}), 25 \mathrm{ppm}(5.12 \mathrm{~mm})$ and $50 \mathrm{ppm}$ $(5.10 \mathrm{~mm})$ BA applications. The next performers were $200 \mathrm{ppm}(4.98 \mathrm{~mm}), 125$ ppm $(4.91 \mathrm{~mm})$ and $75 \mathrm{ppm}(4.81 \mathrm{~mm}) \mathrm{BA}$ applications (Figure - 4.2). The minimum stem girth of African marigold was recorded with $300 \mathrm{ppm}$ BA application $(4.30 \mathrm{~mm})$ that was statistically at par with the effects exerted by Control plants $(4.68 \mathrm{~mm})$ and $250 \mathrm{ppm} \mathrm{BA}$ application $(4.75 \mathrm{~mm})$.

\section{Girth of stem at $\mathbf{4 2}$ days after transplanting} (mm)

Benzyladenine had a significant influence on stem girth of African Marigold at 42 days after transplanting (Table - 4.1). Application of $275 \mathrm{ppm}$ BA solution produced maximum stem girth $(9.36 \mathrm{~mm})$ that was statistically at par with the effects of $25 \mathrm{ppm}(9.04 \mathrm{~mm}), 150$ ppm (8.92 mm), $225 \mathrm{ppm}(8.85 \mathrm{~mm})$ and 125 ppm $(8.53 \mathrm{~mm})$ BA applications (Figure 4.2). The next performers were $100 \mathrm{ppm}(8.48$ $\mathrm{mm}), 175 \mathrm{ppm}(8.28 \mathrm{~mm}), 50 \mathrm{ppm}(8.22 \mathrm{~mm})$ and $250 \mathrm{ppm}(8.16 \mathrm{~mm}) \mathrm{BA}$ treated plants. The minimum girth of stem was obtained from control (Distilled water) plants (7.37 $\mathrm{mm}$ ) which was statistically at par with 75 ppm $(7.81 \mathrm{~mm}) 200 \mathrm{ppm}(7.88 \mathrm{~mm})$ and 300 ppm (7.94 mm) BA applications

\section{Number of shoots per plant at 21 days after transplanting}

The effect of exogenous application of different concentrations of BA on the number of shoots per plant of African Marigold cv. PusaNarangiGainda at 21 days after transplanting was found statistically significant (Table -4.1$)$. The highest number of shoots per plant was recorded with 250 ppm BA application (4.80) which was statistically at par with $150 \mathrm{ppm}$ (4.60) and 25 ppm (4.47) BA applications and the later was also statistically at par with $200 \mathrm{ppm}$ (4.40), $225 \mathrm{ppm}$ (4.40), $100 \mathrm{ppm}$ (4.27), $275 \mathrm{ppm}$ (4.27) and $300 \mathrm{ppm}$ (4.27) BA treated plants as well as control plants (4.20). The least number of shoots per plant was found with 75 ppm BA treated plants (3.80) which were statistically at par with the $50 \mathrm{ppm}$ (3.87), $175 \mathrm{ppm}$ (3.87) and $125 \mathrm{ppm}$ (4.07) BA treatments. 
Number of shoots per plant at 42 days after transplanting

$150 \mathrm{ppm}$ BA treated plants showed highest number of shoots per plant (10.80) of African Marigold cv. PusaNarangiGaindah at 42 days after transplanting (Table-4.1) that was statistically at par with $300 \mathrm{ppm}$ (10.27), 225 ppm (10.13), $250 \mathrm{ppm}$ (10.07), $100 \mathrm{ppm}$ (10.00), 200 ppm (9.60), 25 ppm (9.53), 175 ppm (9.47) and $275 \mathrm{ppm}$ (9.40) BA applications. The control plants produced the minimum number of shoots per plant (7.20) at 42 days after transplanting of African Marigold cv. PusaNarangiGainda.

\section{Shoot length at 21 days after transplanting (cm)}

Different concentrations of BA application on shoot length of African marigold cv. PusaNarangiGainda at 21 days after transplanting was found statistically nonsignificant (Table-4.2). The maximum shoot length $(2.88 \mathrm{~cm})$ was obtained from $175 \mathrm{ppm}$ BA treated plants and the minimum shoot length $(2.15 \mathrm{~cm})$ was noticed with $300 \mathrm{ppm}$ BA application.

\section{Shoot length at 42 days after transplanting (cm)}

Foliar application of different concentrations of BA on African marigold cv. PusaNarangiGainda was found statistically significant in respect of shoot length at 42 days after transplanting (Figure -4.4).

Plants sprayed with $125 \mathrm{ppm}$ BA solution produced maximum shoot length $(13.6 \mathrm{~cm})$ at that stage of crop growth which was found statistically at par with all the rest BA treatments (Table -4.2) except $150 \mathrm{ppm}$ (12.0 $\mathrm{cm})$ and $250 \mathrm{ppm}(11.70 \mathrm{~cm})$. Control plants produced the minimum shoot. length (10.9 $\mathrm{cm})$.
Number of leaves per shoot at 21 days after transplanting

The exogenous application of different concentrations of BA on leaf production of African Marigold cv. PusaNarangiGainda at 21 days after transplanting was found statistically significant (Table - 4.2). Plants treated with $250 \mathrm{ppm}$ BA produced highest number of leaves (3.80) followed by $225 \mathrm{ppm}$ BA application (3.40) which was found statistically at par with the effects of $150 \mathrm{ppm}$ (3.33), $25 \mathrm{ppm}$ (3.27), $75 \mathrm{ppm}$ (3.27), 300 ppm (3.27) and 50 ppm (3.20) BA applications and control plants (3.07). Plants treated with $125 \mathrm{ppm}$ BA produced minimum number of leaves per shoot (2.80) of African Marigold which was statistically at par with $200 \mathrm{ppm}$ (2.93), $100 \mathrm{ppm}$ (3.00), $175 \mathrm{ppm}$ (3.00) and 275 ppm (3.00) BA treatments.

\section{Number of leaves per shoot at $\mathbf{4 2}$ days after transplanting}

$250 \mathrm{ppm}$ BA treated plants again showed maximum leaf production (13.07) of African marigold at 42 days after transplanting (Table - 4.2) followed by 175 ppm BA application (10.27) which was equally effective with 125 ppm BA application (10.00) and the later was also on par with the effects of $25 \mathrm{ppm}$ (9.67) and $75 \mathrm{ppm}$ (9.67) BA applications (Figure 4.5). The minimum number of leaves per shoot was recorded with control plants (7.93) which were found statistically at par with 50 ppm BA application (8.20).

\section{Leaf length at 21 days after transplanting (cm)}

The effect of exogenous application different concentrations of BA on African Marigold cv. PusaNarangiGainda was found statistically significant in respect of leaf length at 21 days after transplanting (Table - 4.2). Plants treated with $25 \mathrm{ppm}$ BA $(13.42 \mathrm{~cm})$ showed 
maximum leaf length which was found statistically at par with the effects of $250 \mathrm{ppm}$ $(13.16 \mathrm{~cm}), 275 \mathrm{ppm}(13.03 \mathrm{~cm}), 225 \mathrm{ppm}$ $(12.64 \mathrm{~cm}), 200 \mathrm{ppm}(12.01 \mathrm{~cm})$ and $150 \mathrm{ppm}$ $(11.88 \mathrm{~cm})$ treated plants (Figure -4.6$)$. The minimum leaf length at that stage was noticed with 50 ppm BA treated plants $(10.61 \mathrm{~cm})$ which was found statistically at par with rest of the BA treatments and Control $(10.85 \mathrm{~cm})$.

\section{Leaf length at 42 days after transplanting (cm)}

Different concentrations of BA application on African Marigold cv. PusaNarangiGainda was found statistically significant in respect of leaf length at 42 days after transplanting (Table 4.2). The longest leaves were produced by 250 ppm BA treated plants $(21.86 \mathrm{~cm})$ which was statistically at par with the effects of 25 ppm $(20.69 \mathrm{~cm}), 275 \mathrm{ppm}(20.37 \mathrm{~cm}), 200$ ppm (19.87 cm), 225 ppm (19.55 cm), 150 ppm (19.55 cm), 125 ppm $(19.48 \mathrm{~cm})$ and 100 ppm $(19.17 \mathrm{~cm})$ BA applications (Figure 4.6). The control plants produced minimum leaf length $(15.37 \mathrm{~cm})$ which was statistically at par with the effect of $300 \mathrm{ppm}$ BA application $(17.90 \mathrm{~cm})$.

\section{Number of leaflets per leaf at 21 days after transplanting}

The exogenous application of different concentrations of BA on number of leaflets per leaf of African Marigold cv. PusaNarangiGainda at 21 days after transplanting was found statistically significant (Table -4.3 ). The data revealed that the application of $225 \mathrm{ppm}$ BA produced the maximum number of leaflets per leaf (Figure - 4.7) of marigold (16.07) which was found statistically on par with the effects of 75 ppm (15.87), 25 ppm (15.67), 175 ppm (15.60) and 50 ppm (15.20) BA applications. Plants when treated with $100 \mathrm{ppm}$ and 150 ppm BA solutions showed moderate effects (14.87 leaflets/leaf) which were at par with the applications of $300 \mathrm{ppm}$ (14.80), $250 \mathrm{ppm}$ (14.73) and 275ppm (14.13) BA and control (14.67) respectively. The lowest number of leaflets per leaf was found in $200 \mathrm{ppm}$ BA treated plants (14.00).

\section{Number of leaflets per leaf at 42 days after transplanting}

Foliar application of BA at different concentrations on African marigold cv. PusaNarangiGainda was found statistically significant with respect to leaflet production (Table - 4.3). Plants treated with 300 ppm BA recorded maximum number of leaflets per leaf (24.07) which was statistically at par with the effects of $225 \mathrm{ppm}$ (23.67) and $150 \mathrm{ppm}$ (23.33) BA applications (Figure- 4.7). Plants treated with $50 \mathrm{ppm}$ BA performed next (23.00) which was statistically at par with the effects of 175 ppm (22.80), 75 ppm (22.40), and $200 \mathrm{ppm}$ (22.27) BA treated plants. All the plant growth regulator treatments showed higher leaflet production than control plants produced the least number of leaflets per leaf (18.87).

\section{Leaflet length at 21 days after transplanting $(\mathrm{cm})$}

The effect of $\mathrm{N}^{6}$ benzyladednine on leaflet length of African marigold cv. PusaNarangiGainda at 21 days after transplanting was found statistically nonsignificant (Table - 4.3). Marigold plants when treated with 200 ppm BA recorded the longest leaflet $(4.93 \mathrm{~cm})$ while the shortest leaflets were reported under the application effects of $25 \mathrm{ppm} \mathrm{BA}(4.32 \mathrm{~cm})$ and $50 \mathrm{ppm}$ BA $(4.32 \mathrm{~cm})$ respectively.

Leaflet length at 42 days after transplanting $(\mathrm{cm})$

Effect of exogenous foliar application of different concentrations of $\mathrm{BA}$ on leaflet length of African Marigold cv. 
PusaNarangiGainda at 42 days after transplanting was found statistically significant (Table - 4.3). Plants treated with $25 \mathrm{ppm}$ BA produced maximum leaflet length $(6.80 \mathrm{~cm})$ which was statistically at par with the application effects of $275 \mathrm{ppm}(6.72 \mathrm{~cm})$, 75 ppm $(6.64 \mathrm{~cm}), 50 \mathrm{ppm}(6.60 \mathrm{~cm}), 100$ ppm $(6.39 \mathrm{~cm}), 150 \mathrm{ppm}(6.62 \mathrm{~cm}), 175 \mathrm{ppm}$ $(6.47 \mathrm{~cm}), 300 \mathrm{ppm}(6.44 \mathrm{~cm}), 200 \mathrm{ppm}(6.27$ $\mathrm{cm}), 125 \mathrm{ppm}(6.25 \mathrm{~cm})$ and $250 \mathrm{ppm}(6.11$ $\mathrm{cm})$ BA respectively (Figure- 4.8). Application of $175 \mathrm{ppm}$ BA $(5.62 \mathrm{~cm})$ followed next and was found as statistically at par with the control $(5.14 \mathrm{~cm})$ reported the shortest length of leaflet at 42 days after transplanting.

\section{Leaflet width at 21 days after transplanting (cm)}

Different concentrations of BA application on leaflet width of African marigold cv. PusaNarangiGainda at 21 days after transplanting was found statistically nonsignificant (Table -4.3 ). Plants treated with $200 \mathrm{ppm}$ BA recorded the maximum width of leaflet $(0.96 \mathrm{~cm})$ while the minimum leaflet width $(0.71 \mathrm{~cm})$ was noticed with $50 \mathrm{ppm}$ BA application.

\section{Leaflet width at 42 days after transplanting (cm)}

Exogenous foliar application of different concentrations of BA on leaflet width at 42 days after transplanting of African marigold cv. PusaNarangiGainda was observed as statistically significant (Table -4.3 ). Leaf expansion was observed better with cytokinin application. Application of 200 ppm BA on marigold plant showed the maximum width of leaflet $(1.33 \mathrm{~cm})$ which was on par with the effects of $25 \mathrm{ppm}(1.32 \mathrm{~cm}), 75 \mathrm{ppm}(1.32$ cm), 50 ppm $(1.27 \mathrm{~cm}), 100$ ppm $(1.23 \mathrm{~cm})$, $175 \mathrm{ppm}(1.23 \mathrm{~cm}), 225 \mathrm{ppm}(1.21 \mathrm{~cm})$ and $275 \mathrm{ppm}(1.21 \mathrm{~cm})$ BA application respectively (Figure- 4.9). Control plants recorded the minimum leaf expansion of African Marigold $(1.04 \mathrm{~cm})$.

Foliar application of different concentrations of BA on time period requirement for flower bud initiation of African Marigold cv. PusaNarangiGainda was found statistically significant (Table - 4.7). Plants treated with $125 \mathrm{ppm}$ BA solution reached the flower bud initiation stage earliest (46.60days after transplanting) which was statistically at par with 275 ppm BA application (47.40days after transplanting) and the later was also on par with 200 ppm BA application (47.73days after transplanting). The plant growth regulator applications showed earliness in flowering over control (49.93 days after transplanting) except at $300 \mathrm{ppm} 100 \mathrm{ppm}$ and 25 ppm levels (Figure-4.15) of which 25 ppm BA treated pants reached the flower bud initiation stage last of all (53 days after transplanting).

\section{Days required for flower bud development (days)}

The exogenous application of different concentrations of BA on time period requirement for flower bud development of African Marigold cv. PusaNarangiGainda was found statistically significant (Table - 4.7). Early flower bud development (Figure -4.15) was noticed with $200 \mathrm{ppm}$ BA treated plants (6.66 days after FBI) which was found statistically at par with all the other levels of BA application except 300 ppm and 225 ppm levels of which $225 \mathrm{ppm}$ BA application required the maximum time period for flower bud development ( 7.73 days after FBI). 
Table.1 Effect of different concentrations of BA on plant height, girth of stem, number of shoots per plant at 21 days and 42 days after transplanting of African Marigold cv. Pusa Narangi Gainda

\begin{tabular}{|c|c|c|c|c|c|c|}
\hline Treatments & $\begin{array}{c}\text { Plant } \\
\text { Height at } \\
21 \text { days } \\
\text { (cm) }\end{array}$ & $\begin{array}{c}\text { Plant } \\
\text { Height at } \\
42 \text { days } \\
\text { (cm) }\end{array}$ & $\begin{array}{c}\text { Girth of } \\
\text { stem at } \\
21 \text { days } \\
\text { (mm) }\end{array}$ & $\begin{array}{c}\text { Girth of } \\
\text { stem at } 42 \\
\text { days }(\mathrm{mm})\end{array}$ & $\begin{array}{c}\text { Number of } \\
\text { shoots per } \\
\text { plant at } 21 \\
\text { days }\end{array}$ & $\begin{array}{l}\text { Number of shoots per } \\
\text { plant at } 42 \text { days }\end{array}$ \\
\hline $\mathbf{T}_{1}$ & 23.19 & 48.13 & 5.12 & 9.04 & 4.47 & 9.53 \\
\hline $\mathbf{T}_{2}$ & 20.30 & 44.77 & 5.10 & 8.22 & 3.87 & 9.13 \\
\hline $\mathbf{T}_{3}$ & 20.33 & 41.71 & 4.81 & 7.81 & 3.80 & 8.73 \\
\hline $\mathbf{T}_{4}$ & 22.13 & 47.01 & 5.12 & 8.48 & 4.27 & 10.00 \\
\hline $\mathbf{T}_{5}$ & 20.11 & 44.76 & 4.91 & 8.53 & 4.07 & 9.00 \\
\hline $\mathbf{T}_{6}$ & 21.68 & 46.17 & 5.87 & 8.92 & 4.60 & 10.80 \\
\hline $\mathbf{T}_{7}$ & 22.45 & 46.39 & 5.22 & 8.28 & 3.87 & 9.47 \\
\hline $\mathbf{T}_{8}$ & 19.79 & 42.25 & 4.98 & 7.88 & 4.40 & 9.60 \\
\hline$T_{9}$ & 22.17 & 47.01 & 5.23 & 8.85 & 4.40 & 10.13 \\
\hline$T_{10}$ & 21.77 & 46.18 & 4.75 & 8.16 & 4.80 & 10.07 \\
\hline$T_{11}$ & 21.81 & 45.77 & 5.25 & 9.36 & 4.27 & 9.40 \\
\hline $\mathbf{T}_{12}$ & 19.55 & 41.95 & 4.30 & 7.94 & 4.27 & 10.27 \\
\hline $\mathbf{T}_{13}$ & 20.47 & 41.89 & 4.68 & 7.37 & 4.20 & 7.20 \\
\hline S.Em ( $( \pm)$ & 0.20 & 0.26 & 0.16 & 0.28 & 0.12 & 0.48 \\
\hline C.D. at $5 \%$ & 0.57 & 0.77 & 0.46 & 0.83 & 0.36 & 1.41 \\
\hline
\end{tabular}

Table.2 Effect of different concentrations of BA on shoot length, number of leaves per shoot and leaf length at 21 days and 42 days after transplanting of African Marigold cv.

PusaNarangiGainda

\begin{tabular}{|c|c|c|c|c|c|c|}
\hline Treatments & $\begin{array}{l}\text { Shoot length } \\
\text { at } 21 \text { days } \\
\text { after } \\
\text { transplanting } \\
\text { (cm) }\end{array}$ & $\begin{array}{l}\text { Shoot length } \\
\text { at } 42 \text { days } \\
\text { after } \\
\text { transplanting } \\
\text { (cm) }\end{array}$ & $\begin{array}{l}\text { Number of } \\
\text { leaves per shoot } \\
\text { at } 21 \text { days after } \\
\text { transplanting }\end{array}$ & $\begin{array}{c}\text { Number of } \\
\text { leaves per shoot } \\
\text { at } 42 \text { days after } \\
\text { transplanting }\end{array}$ & $\begin{array}{l}\text { Leaf length at } \\
21 \text { days after } \\
\text { transplanting } \\
\quad(\mathrm{cm})\end{array}$ & $\begin{array}{c}\text { Leaf length at } \\
42 \text { days after } \\
\text { transplanting } \\
(\mathrm{cm})\end{array}$ \\
\hline$T_{1}$ & 2.71 & 13.1 & 3.27 & 9.67 & 13.42 & 20.69 \\
\hline $\mathbf{T}_{2}$ & 2.41 & 13.4 & 3.20 & 8.20 & 10.61 & 18.51 \\
\hline $\mathbf{T}_{3}$ & 2.54 & 13.0 & 3.27 & 9.67 & 10.83 & 18.74 \\
\hline $\mathbf{T}_{4}$ & 2.66 & 12.8 & 3.00 & 8.80 & 11.05 & 19.17 \\
\hline $\mathbf{T}_{5}$ & 2.52 & 13.6 & 2.80 & 10.00 & 11.40 & 19.48 \\
\hline$T_{6}$ & 2.69 & 12.0 & 3.33 & 9.40 & 11.88 & 19.55 \\
\hline $\mathbf{T}_{7}$ & 2.88 & 14.1 & 3.00 & 10.27 & 10.96 & 18.73 \\
\hline $\mathbf{T}_{8}$ & 2.67 & 12.7 & 2.93 & 8.47 & 12.01 & 19.87 \\
\hline $\mathbf{T}_{9}$ & 2.51 & 13.0 & 3.40 & 8.53 & 12.64 & 19.55 \\
\hline $\mathbf{T}_{10}$ & 2.49 & 11.7 & 3.80 & 13.07 & 13.16 & 21.86 \\
\hline$T_{11}$ & 2.53 & 12.7 & 3.00 & 9.53 & 13.03 & 20.37 \\
\hline $\mathbf{T}_{12}$ & 2.15 & 12.1 & 3.27 & 9.47 & 11.35 & 17.90 \\
\hline $\mathbf{T}_{13}$ & 2.65 & 10.9 & 3.07 & 7.93 & 10.85 & 15.37 \\
\hline S. Em ( $( \pm)$ & 0.06 & 0.54 & 0.12 & 0.65 & 0.65 & 0.94 \\
\hline C. D. at $5 \%$ & N.S. & 1.58 & 0.34 & 0.51 & 1.89 & 2.74 \\
\hline
\end{tabular}


Table.3 Effect of different concentrations of BA on number of leaflets per leaf, leaflet length and leaflet width at 21 days and 42 days after transplanting of African Marigold cv.

PusaNarangiGainda

\begin{tabular}{|c|c|c|c|c|c|c|}
\hline Treatments & $\begin{array}{l}\text { Number of } \\
\text { leaflets per leaf } \\
\text { at } 21 \text { days after } \\
\text { Transplanting }\end{array}$ & $\begin{array}{l}\text { Number of } \\
\text { leaflets per } \\
\text { leaf at } 42 \text { days } \\
\text { after } \\
\text { Transplanting }\end{array}$ & $\begin{array}{l}\text { Leaflet length } \\
\text { at } 21 \text { days after } \\
\text { Transplanting } \\
(\mathrm{cm})\end{array}$ & $\begin{array}{l}\text { Leaflet length at } \\
42 \text { days after } \\
\text { Transplanting } \\
\text { (cm) }\end{array}$ & $\begin{array}{l}\text { Leaflet width at } \\
21 \text { days after } \\
\text { Transplanting } \\
\text { (cm) }\end{array}$ & $\begin{array}{l}\text { Leaflet width } \\
\text { at } 42 \text { days after } \\
\text { Transplanting } \\
\text { (cm) }\end{array}$ \\
\hline $\mathbf{T}_{1}$ & 15.67 & 21.87 & 4.32 & 6.80 & 0.81 & 1.32 \\
\hline $\mathbf{T}_{2}$ & 15.20 & 23.00 & 4.32 & 6.60 & 0.71 & 1.27 \\
\hline $\mathbf{T}_{3}$ & 15.87 & 22.40 & 4.80 & 6.64 & 0.90 & 1.32 \\
\hline $\mathbf{T}_{4}$ & 14.87 & 21.47 & 4.64 & 6.39 & 0.87 & 1.23 \\
\hline $\mathbf{T}_{5}$ & 14.07 & 21.80 & 4.36 & 6.25 & 0.78 & 1.11 \\
\hline$T_{6}$ & 14.87 & 23.33 & 4.74 & 6.62 & 0.79 & 1.19 \\
\hline $\mathbf{T}_{7}$ & 15.60 & 22.80 & 4.43 & 5.62 & 0.83 & 1.23 \\
\hline $\mathbf{T}_{8}$ & 14.00 & 22.27 & 4.93 & 6.27 & 0.96 & 1.33 \\
\hline $\mathbf{T}_{9}$ & 16.07 & 23.67 & 4.74 & 6.47 & 0.79 & 1.21 \\
\hline $\mathbf{T}_{10}$ & 14.73 & 20.60 & 4.67 & 6.11 & 0.76 & 1.14 \\
\hline$T_{11}$ & 14.13 & 20.60 & 4.87 & 6.72 & 0.89 & 1.21 \\
\hline $\mathbf{T}_{12}$ & 14.80 & 24.07 & 4.54 & 6.44 & 0.75 & 1.20 \\
\hline $\mathbf{T}_{13}$ & 14.67 & 18.87 & 4.35 & 5.14 & 0.81 & 1.04 \\
\hline S. $\operatorname{Em}( \pm)$ & 0.34 & 0.29 & 0.24 & 0.30 & 0.06 & 0.42 \\
\hline C. D. at $5 \%$ & 1.00 & 0.83 & N.S. & 0.86 & N.S & 0.123 \\
\hline
\end{tabular}

Table.4 Effect of different concentrations of BA in days required for flower bud initiation (FBI), flower bud development (FBD) and full blooming (FB) of African marigold cv.

PusaNarangiGainda

\begin{tabular}{|l|c|c|c|}
\hline Treatments & $\begin{array}{c}\text { Days required for } \\
\text { FBI (days) }\end{array}$ & $\begin{array}{c}\text { Days required for } \\
\text { FBD (days) }\end{array}$ & $\begin{array}{c}\text { Days require for FB } \\
\text { (days) }\end{array}$ \\
\hline $\mathbf{T}_{\mathbf{1}}$ & 53 & 7.00 & 6.60 \\
\hline $\mathbf{T}_{\mathbf{2}}$ & 49.07 & 7.47 & 6.93 \\
\hline $\mathbf{T}_{\mathbf{3}}$ & 49.60 & 6.80 & 7.20 \\
\hline $\mathbf{T}_{\mathbf{4}}$ & 51.60 & 7.47 & 6.87 \\
\hline $\mathbf{T}_{\mathbf{5}}$ & 46.40 & 7.60 & 6.80 \\
\hline $\mathbf{T}_{\mathbf{6}}$ & 49.60 & 7.53 & 6.73 \\
\hline $\mathbf{T}_{\mathbf{7}}$ & 48.40 & 6.73 & 7.67 \\
\hline $\mathbf{T}_{\mathbf{8}}$ & 47.73 & 6.66 & 7.47 \\
\hline $\mathbf{T}_{\mathbf{9}}$ & 48.93 & 7.73 & 6.87 \\
\hline $\mathbf{T}_{\mathbf{1 0}}$ & 49.40 & 7.20 & 7.27 \\
\hline $\mathbf{T}_{\mathbf{1 1}}$ & 47.40 & 7.40 & 7.40 \\
\hline $\mathbf{T}_{\mathbf{1 2}}$ & 51.33 & 7.67 & 7.47 \\
\hline $\mathbf{T}_{\mathbf{1 3}}$ & 49.93 & 7.40 & 8.20 \\
\hline S. $\mathbf{E m} \mathbf{( \pm )}$ & $\mathbf{1 . 2 0}$ & $\mathbf{0 . 3 4}$ & $\mathbf{0 . 2 4}$ \\
\hline C. $\mathbf{D}$ at $\mathbf{5 \%}$ & $\mathbf{3 . 4 8}$ & $\mathbf{1 . 0 0}$ & $\mathbf{0 . 7 0}$ \\
\hline
\end{tabular}


Days required for full blooming of flowers (days)

Effect ofdifferent concentrations of BA applied on African Marigold cv. PusaNarangiGainda regarding time period required for full blooming of flowers was observed statistically significant. Plants treated with $25 \mathrm{ppm}$ BA recorded the minimum time period (6.60 days after FBD). All the levels of BA application showed lesser time period requirement than Control (Table 4.7), that reached the full blooming stage (Figure-4.15) last of all (8.20 days after FB

In conclusion, African marigold is the ace loose flower of the country having multifarious uses. Considering the importance of African marigold as a commercial flower, the present experiment was undertaken to evaluate the effect of exogenous application of cytokinin in the form of foliar spray on the growth, development, flowering and quality of flowers in a promising cultivar PusaNarangiGainda. The experiment was conducted at the instructional farm of Department of Floriculture, Medicinal and Aromatic Plants, Faculty of Horticulture, Uttar BangaKrishiViswavidyalaya, Pundibari, Coochbehar, West Bengal, India, in the crop growing season from November 2016 to march 2017. The experiment was conducted following RBD with 12 different levels of cytokinin ranging from $25 \mathrm{ppm}, 50 \mathrm{ppm}, 75$ ppm, 100 ppm, 125 ppm. 150 ppm, 175 ppm, $200 \mathrm{ppm}, 225 \mathrm{ppm}, 250 \mathrm{ppm}, 275 \mathrm{ppm}$ and $300 \mathrm{ppm}$ and compared to control (distilled water spray). The 13 treatments were replicated thrice. Results revealed that application of $25 \mathrm{ppm}$ BA increased the plant height at 21 days after transplanting (23.19 $\mathrm{cm})$, plant height at 42 days after transplanting $(48.13 \mathrm{~cm})$, leaflet length at 21 days after transplanting $(4.32 \mathrm{~cm})$, Leaflet length at 42 days after transplanting (6.80 $\mathrm{cm})$, Increase in the girth of stem at 42 days after transplanting was noticed with $275 \mathrm{ppm}$ BA application $(9.36 \mathrm{~mm})$. Initially, sideshoot production was increased with $200 \mathrm{ppm}$ BA application $(4.80 \mathrm{~cm})$ but at 42 days after transplanting higher number of side-shoots was obtained with $150 \mathrm{ppm}$ BA application $(10.80 \mathrm{~cm})$. Shoot length was found maximum with $175 \mathrm{BA}$ application both at 21 days $(2.88 \mathrm{~cm})$ and 42 days after transplanting $(14.0 \mathrm{~cm})$. Leaf production was found maximum with $250 \mathrm{ppm}$ BA application in both at 21 days (3.80) and 42 days (13.07) after transplanting. The same treatment also showed higher leaf length at 42 days after transplanting $(21.86 \mathrm{~cm})$. Though at 21 days leaflet production was higher with $225 \mathrm{ppm}$ BA application (16.07) but at 42 days after transplanting $300 \mathrm{ppm}$ BA application showed higher leaflet production (24.07). Initially $200 \mathrm{ppm}$ BA application improved leaflet length $(4.93 \mathrm{~cm})$ but finally maximum leaflet length was found with $25 \mathrm{ppm}$ BA application. Leaf expansion was observed higher with foliar application of $200 \mathrm{ppm}$ BA in both at 21 days $(0.96 \mathrm{~cm})$ and 42 days after transplanting $(1.33 \mathrm{~cm})$. Plants treated with same concentration reached the flower bud initiation stage earliest (46.60 days after transplanting). Whereas, $200 \mathrm{ppm}$ solution showed least time period (6.66 days) for flower bud development and from the developing bud to full bloom stage, $25 \mathrm{ppm}$ BA concentration showed the earliness $(6.60$ days). In the present experiment exogenous application of $25 \mathrm{ppm} \mathrm{BA}$ as foliar spray at 15 and 30 days after transplanting and the earliness flower obtain from 25ppm dose BA application.So, hence may be recommended (25ppm BA) forgrowth parameter of African marigold cv. PusaNarangiGainda in the Terai region of West Bengal.

\section{References}

Dixit P, Tripathi S, Verma K N. 2013.A brief study on marigold (tagetes species): a 
review. International research journal of pharmacy4(1).

Gowle S K, Chaturvedi M K and Yadaw K N. 2012. Adoption pattern of improved marigold production technologies by the farmers in Bilaspur district of chhattishgar. Agriculture updates 7(3/4): 324-329.

Kumar S, Srinivasa V, Praneeth S Y, Jayasheela, S D and Gokavi N. 2015. evaluation of marigold (tageteserecta 1.) genotypes for growth, yield and quality under hill zone of Karnataka.Ecology,
Environment and Conservation Paper 21: (1743-1747).

Panero J L and Funk V A. 2002. Toward a phylogenetic subfamilial classification for the Compositae (Asteraceae). Proceedings of the Biological Society of Washington 115(4): 909-922.

Sudhagar S. 2013.Production and Marketing of loose flowers.International Journal of Business and Management Invention $2: 15-25$

\section{How to cite this article:}

Manas Mandal, Soumen Maitra, Anamay Sarkar, Bappa Paramanik, Indrajit Sarkar and Debasis Mahata. 2019. Studies on the Effect of Cytokinin on Growth of African Marigold (Tagetes erecta L.) cv. Pusa Narangi Gainda. Int.J.Curr.Microbiol.App.Sci. 8(08): 2327-2336. doi: https://doi.org/10.20546/ijcmas.2019.808.269 